\title{
sciendo
}

CIVIL AND ENVIRONMENTAL ENGINEERING REPORTS

E-ISSN 2450-8594

CEER 2021; 31 (3): 0099-0117

DOI: 10.2478/ceer-2021-0036

Original Research Article

\section{COMPARATIVE ANALYSIS OF THREE DIFFERENT NEGATIVE EMISSION TECHNOLOGIES, BECCS, ABSORPTION AND ADSORPTION OF ATMOSPHERIC $\mathrm{CO}_{2}$}

\author{
Saeed TALEI ${ }^{1}$, Zahra SOLEIMANI ${ }^{2}$ \\ ${ }^{1}$ Process Engineer, Energy and Environment Research Center of Niro Research institute \\ (NRI), Tehran, Iran \\ ${ }^{2}$ Department of Chemistry and Petroleum Science, Shahid Beheshti University, Tehran, \\ Iran
}

\begin{abstract}
Negative Emission Technologies (NETs) are generally considered as vital methods for achieving climate goals. To limit the rise in the global average temperature below $2{ }^{\circ} \mathrm{C}$, a large number of countries that participated in the Paris agreement was virtually unanimous about the effective collaboration among members for the reduction of $\mathrm{CO}_{2}$ emissions throughout this century. NETs on the ground that can remove carbon dioxide from the atmosphere, provide an active option to achieve this goal.

In this contribution, we compare limiting factors, cost, and capacity of three different NETs, including bioenergy with carbon capture and storage (BECCS), absorption and adsorption. Although there are several advantages for capturing $\mathrm{CO}_{2}$, still some constraints regarding the high operational cost of NETs and industrial condition of these technologies as a method of climate change mitigation is not clear. Thereby no single process can be considered as a comprehensive solution. Indeed, any developed technologies, in turn, have a contribution to the reduction of $\mathrm{CO}_{2}$ concentration. Extensive research needs to be done to assess and decrease NETs costs and limitations.
\end{abstract}

${ }^{1}$ Process Engineer, Energy and Environment Research Center of Niro Research institute (NRI), Tehran, Iran; e-mail: talei.saeed66@gmail.com 
Keywords: negative emission technology, climate change, BECCS, absorption, adsorption, $\mathrm{CO}_{2}$

\section{INTRODUCTION}

Undoubtedly, global warming has arisen from rising greenhouse gas (GHG) concentration in the atmosphere is the paramount important environmental concern throughout the world $[4,76,88]$. the high concentration of greenhouse gases in the atmosphere causes various environmental problems such as floods, the increasing number of ocean storms, continuous rise of water level in the sea, melting the ice cap, etc. $[2,17,55,61,95]$.

$\mathrm{CO}_{2}$ as one of the greenhouse gases has a higher contribution to global warming than other gases which accounts for almost more than 55\% of global warming [32]. After the industrial revolution, the atmospheric concentration of $\mathrm{CO}_{2}$ has risen rapidly by $50 \%[3,35,89]$.

Despite efforts have been done to mitigate negative consequences of $\mathrm{CO}_{2}$ emissions and other greenhouse gases (GHGs) since two decades ago, the rate of greenhouse gas emissions in the 2000s increased more than in comparison to the previous decade and by 2010 had reached approximately to $50 \mathrm{Gt}^{\mathrm{CO}_{2}}$ per year $[54,67]$. The zero tolerance policy should be considered for the reduction of global atmospheric $\mathrm{CO}_{2}$ concentration to reach the international goal of limiting warming to less than $2^{\circ} \mathrm{C}$ compared to before the industrial era $[1,11,25]$.

Recently, a large proportion of climate mitigation efforts focus on reducing emissions of $\mathrm{CO}_{2}$ to the atmosphere, for example by increasing the energy efficiency of technologies, switching to low or zero-carbon fuel sources, and negative emission technologies[22,26,49,77,90].

A large number of scenarios was assessed by the international panel on climate change (IPCC) to reduce atmospheric $\mathrm{CO}_{2}$ concentration, these scenarios used to estimate the $2{ }^{\circ} \mathrm{C}$ with $66 \%$ likelihood carbon budget showing the necessity of negative emissions technologies [20,23,46,74,79,93].

Based on estimates was done by Rogelj et al [79] in 2011, two main urgent actions are set to be required; more reductions in fossil fuel utilization or more carbon dioxide removal.

Negative emissions technologies as feasible solutions provide effective ways to capture and reduce the amount of $\mathrm{CO}_{2}$ in the atmosphere to achieve the international target of $\mathrm{CO}_{2}$ concentration in the atmosphere. It is essential to note that the deployment of NETs needs to be received financial aids by governmental due to the lack of tax incentive financed by fossil energy users [6].

There are two different methods of NETs, direct air capture and indirect air capture, as shown in table 1, distinct techniques exist regarding to these methods such as: (1) BECCS [13,15,45,53,57], (2) afforestation and reforestation (AR) 
[36,85], (3) absorption [40], (4) adsorption [5], (5) biochar [27,99], (6) soil carbon sequestration [80,101], (7) ocean fertilization [50,97], (8) ocean alkalinity enhancement (OAE) [56,75], and (9) algae culture [10,12].

This paper summarizes an overview of the options and the current status of the three main different NETs, such as BECCS, absorption, and adsorption for capturing atmospheric $\mathrm{CO}_{2}$. Also, in this paper, we examine three distinct features of each technology, including limiting factors, potential capacity, and cost estimate.

Table 1. Negative Emission Technologies

\begin{tabular}{|c|c|c|c|}
\hline Method & Technique & $\begin{array}{l}\mathrm{CO}_{2} \text { Removal } \\
\text { Mechanism }\end{array}$ & $\begin{array}{c}\mathrm{CO}_{2} \text { Storage \& } \\
\text { utilization Method }\end{array}$ \\
\hline \multirow{5}{*}{ 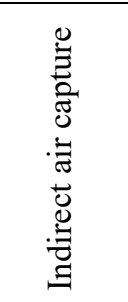 } & BECCS [13] & $\begin{array}{l}\text { Biological }+\mathrm{CO}_{2} \\
\text { Capture }\end{array}$ & $\begin{array}{l}\text { Deep Geological } \\
\text { Formations }\end{array}$ \\
\hline & $\mathrm{AR}[85]$ & Biological & Soils \\
\hline & Ocean fertilization [97] & Biological & Ocean \\
\hline & Biochar [27] & Biological & Soils \\
\hline & Algae culture [10] & Biological & Energy production \\
\hline \multirow{4}{*}{ 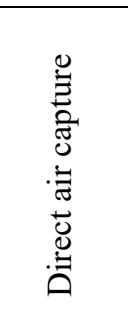 } & Absorption[40] & Chemical & $\begin{array}{l}\text { Deep Geological } \\
\text { Formations }\end{array}$ \\
\hline & Adsorption [5] & Physical & $\begin{array}{l}\text { Deep Geological } \\
\text { Formations }\end{array}$ \\
\hline & $\begin{array}{lll}\text { Soil } & \text { carbon } & \text { sequestration } \\
{[101]} & & \\
\end{array}$ & Biological & Soils \\
\hline & Ocean Alkalinity [56] & Chemical & Ocean \\
\hline
\end{tabular}

\section{INDIRECT AIR CARBON CAPTURE}

Atmospheric $\mathrm{CO}_{2}$ is captured in the natural process of the carbon cycle and then converts into the organic carbon by the photosynthesis reaction, while oxygen is made as a product of this reaction [28]. Compared to direct capture methods, the most important advantage of the biological route is that it requires less energy [59]. Moreover, the operating and investment cost of direct air capture is expensive, and until now the long-term efficiency of it has unproven [24]. The indirect air capture can be separated into five different processes: (1) ocean fertilization, (2) biochar, (3) AR, (4) Algae culture, and (5) BECCS. Because the BECCS process received more attention in the last two decades in comparison to the indirect carbon capture processes, it is described in the next section. 


\subsection{Bioenergy with carbon capture and storage}

BECCS is a geoengineering technique to remove carbon dioxide from the atmosphere that is the combination of biomass combustion and Carbon Capture and storage (CCS). It is possible to use biomass as a fuel source in two different ways, combustion of it as single fuel for power generation or using it in combination with other conventional sources of energy such as natural gas or coal (co-fired generation) $[9,38,69]$. CCS is a technology that can capture carbon dioxide emissions produced from the use of fossil fuels in industrial processes, preventing carbon dioxide from entering the atmosphere. The CCS consists of three parts; capturing carbon dioxide, transporting the carbon dioxide, and securely storing carbon dioxide emissions, underground in deep geological formations. Whereas the combination of CSS and biomass reduces the atmospheric $\mathrm{CO} 2$ by taking it temporarily locked in plants and then storing it permanently in geological formation, it is known as negative emission technology $[8,16,83]$.

BECCS technology is considered an appropriate way to respond to the problems caused by global warming in the current century $[42,62]$. According to some studies, the BECCS has the potential of capturing an acceptable rate of atmospheric $\mathrm{CO} 2$ that if combined with other mitigation options, could help to reduce $\mathrm{CO} 2$ concentration to pre-industrial level [51,72], while contributing to global economic growth [91]. Creutzig et al [15] examined the strength of BECCS as a long-term mitigation approach. They declared that this method can use for a large number of technologies with various $\mathrm{CO} 2$ emissions range such as biomass refineries, power plants or biomass gasification plants [92]. BECCS as one of the significant technology among the negative emission technologies can help to reach the international temperature goal. Moreover, negative emissions that arise from the deployment of the BECCS process can compensate for the residual emissions in other sectors, such as paper, cement, and steel industries or in the transportation sector.

The extensive demand for land is considered as one of the main side-effects of BESSC. This can weaken both the capability of negative emissions if greenhouse gas emissions from biomass supply chain are considered [92] and also the potential of land for use of food production and other purposes [92]. Thereby, it is crucial to allocate the marginal land as well as waste biomass feedstocks to benefit more from BECCS implementation. The BECCS potential has been evaluated by the different countries throughout the world, for example, using organic waste from the forestry, agricultural, and municipal sectors was implemented by Australia [70].

Recently, some studies identified the environmental and economic impacts of four BECCS options; bagasse, solid waste of municipal, forest residual, and landfill gases which are combusted in a gas turbine. The cost-effectiveness of negative 
emission was studied in Brazil using sugar cane, bagasse, and other residuals to produce ethanol and electricity simultaneously [63]. The Nordic countries have the largest potential of biomass in the world, this feature facilitated the deployment of BECCS in this region [81]. Moreover, the use of biomass is widespread in other regions of the world. In Korea [44] and Austria [84], domestic biomass use as a bioenergy source. In North America, the use of agricultural residues and wastes are common because they have the potential to achieve a $145 \%$ emission reduction by 2050 compared to 1990 s levels [82].

The concept of BECCS depicts in fig 1 . In this process, $\mathrm{CO}_{2}$ produces after the combustion of biological materials (biofuel, biomass, and biogas) and then captures from flue gas via one of the three different $\mathrm{CO}_{2}$ capture technologies, namely Post combustion, pre combustion, and oxy combustion [18]. Finally, approximately pure $\mathrm{CO}_{2}$ which is released can be used in different industrial processes or stored in the geological formations, these two processes lead to neutral emissions and negative emissions, respectively.

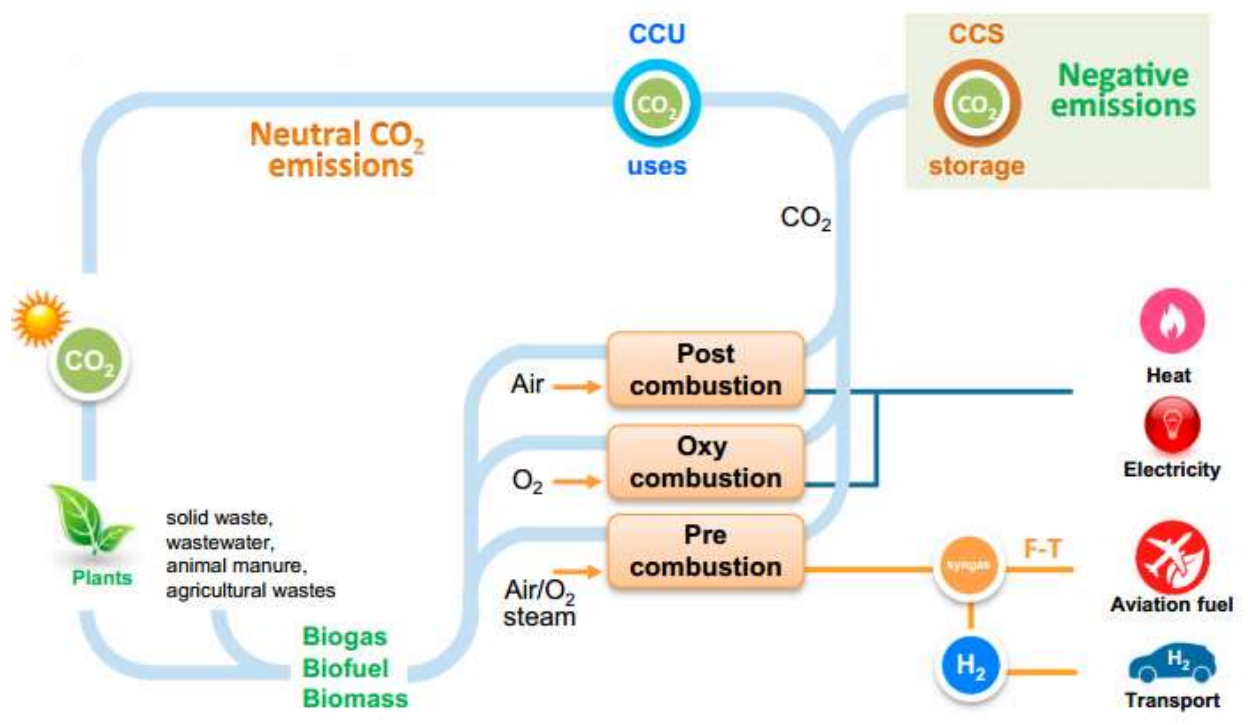

Fig.1. Bioenergy with carbon capture and storage [60]

Biomass has been used generally as an energy source in the history of humankind. The combination of biomass and CCS for the first time was identified by Williams et al [98] in the hydrogen production process, and by Herzog for power generation in 1996 [30].

According to the scientific predictions the contribution of biomass use in the energy system can exceed by $27 \%$ in 2050 [21]. In the shorter term, Panoutsou et 
al [66] and Hoefnagels et al [31] estimated the potential share of biomass in Europe's energy system in 2020 to increase to $10.6 \%$ and $14.0 \%$, respectively. Besides, Schakel et al [83] identified the technical potential of six different BECCS options that co-fired with other sources of fuels.

Although Biomass has some limitations such as lower heating value compared to coal and higher moisture content, it has low $\mathrm{NO}_{\mathrm{x}}$ and $\mathrm{SO}_{\mathrm{X}}$ emissions. Moreover, owing to the assessment of this technology that has been done recently, the capability of deployment this technology on a commercial scale is still unclear $[25,94]$. Besides, one of the most concerning issues regarding the CCS is the safety of the $\mathrm{CO}_{2}$ storage process that still does not accept by the general public [94].

\section{DIRECT AIR CARBON CAPTURE}

Formulae, In addition to indirect capture, DAC is considered as an alternative route for capturing $\mathrm{CO}_{2}$ from the atmosphere. In this approach atmospheric $\mathrm{CO}_{2}$ captures via industrial processes $[7,47]$. DAC is a relatively new and innovative technology in early commercial stages [65], which can help humankind to mitigate the dire consequences of global warming by using conventional technologies in the long term $[39,64]$.

The economic feasibility of DAC systems have investigated in several pieces of literature. They reported costs ranging from $\$ 30$ to $\$ 1000$ per ton of removed $\mathrm{CO}_{2}$ [33]. According to the arguments on physics, thermodynamics, and entropy, the cost of this technology has been widely criticized [73]. However, there is still no comprehensive agreement on the economic feasibility of this process. For example, Simon et al [86] argued that owing to climate mitigation scenarios DAC can be cost-effective in the future, while Ranjan and Herzog [71] asserted that the costs of DAC systems in comparison to other mitigation approaches is high. The atmospheric $\mathrm{CO}_{2}$ can be directly captured by the following methods [96,105]: (1) absorption and (2) adsorption.

\subsection{Absorption}

Absorption technology for capturing carbon dioxide using alkaline solution has been explored since half a century ago. $[19,104]$. For the first time, using large scale scrubbing of $\mathrm{CO}_{2}$ from ambient air as a climate mitigation technology was suggested by Lackner in the late 1990s [48]. In wet scrubbing techniques, $\mathrm{CO}_{2}$ is absorbed into a solution of sodium hydroxide $(\mathrm{NaOH})$ or potassium hydroxide $(\mathrm{KOH})$. According to fig 2, two successive cycles can happen simultaneously for aqueous solutions.

In the first cycle, the ambient air enters to the process with the help of existing fans in the system and then in contact with the $\mathrm{NaOH}$ which is sprayed as a solvent in the process and sodium carbonate $\left(\mathrm{Na}_{2} \mathrm{CO}_{3}\right)$ is formed by reaction of $\mathrm{CO}_{2}$ 
molecules and sodium hydroxide (Eq. 3.1). Then, the rich- $\mathrm{CO}_{2}$ solution is sent to the regeneration cycle and the air with a lower concentration of $\mathrm{CO}_{2}$ leaves the column.

In the regeneration cycle, $\mathrm{NaOH}$ is recovered as a result of the reaction between $\mathrm{Na}_{2} \mathrm{CO}_{3}$ with calcium hydroxide $\left(\mathrm{Ca}(\mathrm{OH})_{2}\right)$ in the causticiser unit (Eq. 3.2). Then $\mathrm{NaOH}$ is sent back to the absorption cycle. Simultaneously, in the most energyintensive step, pure $\mathrm{CO}_{2}$ is released by a reaction that $\mathrm{CaCO}_{3}$ is heated up to about $900{ }^{\circ} \mathrm{C}$ and $\mathrm{CO}_{2}$ collected afterward (Eq. 3.3).

In the last step, water is mixed with $\mathrm{CaO}$ in the slaker unit for $\mathrm{Ca}(\mathrm{OH})_{2}$ regeneration (Eq.3.4).

$\begin{array}{ll}\text { Contactor } & 2 \mathrm{NaOH}+\mathrm{CO}_{2} \rightarrow \mathrm{Na}_{2} \mathrm{CO}_{3}+\mathrm{H}_{2} \mathrm{O} \\ \text { Causticiser } & \mathrm{Na}_{2} \mathrm{CO}_{3}+\mathrm{Ca}(\mathrm{OH})_{2} \rightarrow 2 \mathrm{NaOH}+\mathrm{CaCO}_{3} \\ \text { Calciner } & \mathrm{CaCO}_{3}+\mathrm{Heat} \rightarrow \mathrm{CaO}+\mathrm{CO}_{2} \\ \text { Slaker } & \mathrm{CaO}+\mathrm{H}_{2} \mathrm{O} \rightarrow \mathrm{Ca}(\mathrm{OH})_{2}\end{array}$

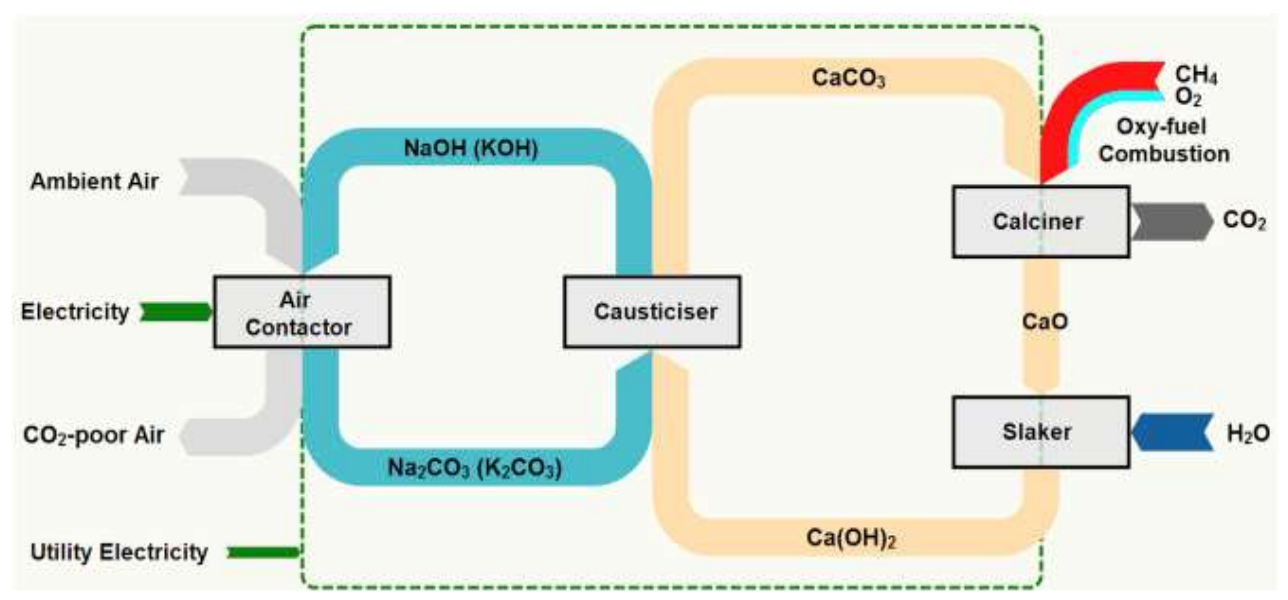

Fig.2. Absorption air capture with sodium hydroxide $(\mathrm{NaOH})$ and potassium hydroxide $(\mathrm{KOH})[41]$

According to literature reports, the efficiency of $\mathrm{CO}_{2}$ absorption on new materials based on amide polymeric ionic liquids is currently being investigated. New class of amide-based polymer ionic liquids, which are characterized by high $\mathrm{CO}_{2}$ capture efficiency, it may be characterized by low costs and high $\mathrm{CO}_{2}$ capture efficiency. 


\subsection{Adsorption}

In this process, air is pumped and then passed through the filter that is coated by alkaline adsorbents. Regeneration of filters is the most important financial limitation in the desorption process. To decrease the recovery cost of $\mathrm{CO}_{2}$, using regenerable adsorbents that can be utilized in multiple cycles paramount important [52]. Pressure swinging adsorption (PSA) and temperature swinging adsorption (TSA) are common methods for $\mathrm{CO}_{2}$ desorption. PSA is a technology for gas separation under high pressure according to the gas characteristics in the adsorption process, then the desorption process happens at a pressure close to the atmospheric pressure. In TSA, hot air or steam is injected to raise the system temperature to regenerate the solid adsorbents from absorbed $\mathrm{CO}_{2}$ [52]. Although the regeneration time for TSA is much longer than PSA, some features of TSA such as the potential for high recovery of $\mathrm{CO}_{2}$ with a relatively pure concentration that is reduced the energy demand to pressurized $\mathrm{CO}_{2}$ is considered as the main advantage of this process.

In commercial sectors for the high concentration of $\mathrm{CO}_{2}$ in the air, the adsorption process has several practical advantages in comparison to the absorption process. Thermal durability in different conditions, the lower energy requirement for regeneration, resistance to corrosion, and the lower environmental concern for the solid waste compared to the liquid waste are the main superiorities of adsorption. [103].

In the selection of adsorbents three main features such as the regeneration ability, specific surface area, and the selectivity of adsorbents should be considered. Activated carbon and zeolites are two types of adsorbents that have been used recently because they have higher stability and selectivity even at low concentrations [102 ].

Wurzbacher et al. [100] assessed the performance of amine-functionalized sorbents for the extraction of $\mathrm{CO}_{2}$ from the air in the adsorption and desorption processes by TSA.

In 2017, the Swiss company, Climeworks, commissioned the world's first commercial DAC plant (fig.3). In this plan which is worked according to desorption and adsorption processes with alkaline adsorbents, $\mathrm{CO}_{2}$ is chemically bonded to the absorbents located on the filter and then $\mathrm{CO}_{2}$ desorbed by TSA. During the TSA process, the temperature is raised from 80 to $120{ }^{\circ} \mathrm{C}$ while the pressure in the system is decreased simultaneously, thereby captured $\mathrm{CO}_{2}$ is released. Then the process is repeated after the cooling stage [29]. 

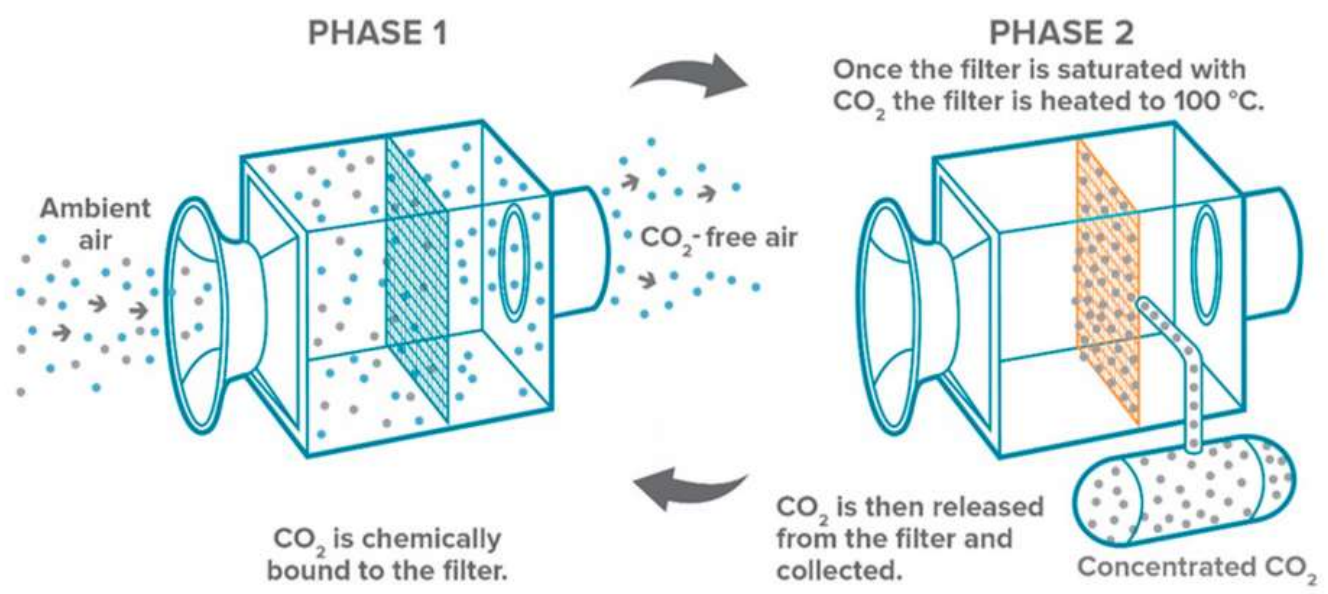

Fig.3. Schematic illustration of Climeworks direct air capture process [29]

According to the climate policies NETs are a valid option for supporting climate change targets. Many accounting frameworks consider these technologies as one of the vital approaches to mitigate the dire consequences of global warming. We already mentioned three different technologies, BECCS, absorption, and adsorption to reach a fairly clear conclusion, the important issues regarding these technologies should be addressed, including limiting factors, the potential capacity of atmospheric $\mathrm{CO}_{2}$ capture and cost estimates of each technology.

Amine-functionalized solids are other types of adsorbents that have been used recently because they have higher stability and selectivity even at low concentrations.

\section{LIMITING FACTORS}

In table 2 the limiting factors associated with each technology are represented. The leading limiting factor related to all the NETs is the storage capacity of $\mathrm{CO}_{2}$ in geological formations [59]. According to the former estimations approximately the storage capacity of $1200 \mathrm{Gt}$ for $\mathrm{CO}_{2}$ captured by NETs is needed. It seems that it is possible to store around half of this figure with techniques that do not rely on geological storage. BECCS on the ground that it has an energy penalty associated with CCS technology would require more storage approximately between 750$900 \mathrm{Gt} \mathrm{CO}_{2}$. It might be that the absorption and adsorption also need additional storage, especially when fossil energy were utilized to power wet calcination, a factor of 2.0 might be applied [87]. If alternative methods for storage such as 
basaltic injection can be used at acceptable cost instead of geological storage, then this figure may be declined [43].

Moreover, availability of land, water, and fertilizer are other constraints regarding to BECCS, Christopher Consoli [14] estimated that if we want to meet $\mathrm{CO}_{2}$ emission target, it would need two times more than the annual world use of water for agriculture and twenty times the annual use of nutrients, and also need 300700 million hectares land. A significant amount of water is lost in the adsorption process (at $15^{\circ} \mathrm{C}$ and $65 \%$ relative humidity, approximately $20 \mathrm{~mol} \mathrm{H}_{2} \mathrm{O}$ per mol of $\mathrm{CO}_{2}$ ), which optimization of system and operation condition can be decreased it. [68].

Table 2. Limiting factors of absorption, adsorption, and BECCS

\begin{tabular}{|l|l|}
\hline \multicolumn{1}{|c|}{ Limiting factors } & \multicolumn{1}{c|}{ Technology } \\
\hline $\mathrm{CO}_{2}$ Storage capacity [59] & BECCS, Absorption, Adsorption \\
\hline Sustainable supply raw materials [59] & BECCS, supply of biomass. \\
& $\begin{array}{l}\text { Absorption, absorbers selection } \\
\text { Adsorption, adsorbers selection }\end{array}$ \\
\hline & \\
\hline Availability of land, water and fertilizers [14] & BECCS \\
\hline Corrosion [59] & Absorption \\
\hline Water loss [68] & Absorption \\
\hline
\end{tabular}

\section{5. $\mathrm{CO}_{2}$ CAPTURE CAPACITY}

The annual potential capacity of the NETs according to the forecast estimates until 2050 , represents in table 3 . The figures for both absorption and adsorption was estimated $10 \mathrm{Gt} \mathrm{CO}_{2}$ per year [57], these figures change according to the adsorbent or solution and percentage of atmospheric $\mathrm{CO}_{2}$ that use in these processes. BECCS capacity is predicted to be 2.4-10 Gt per year, the total global $\mathrm{CO}_{2}$ capacity is estimated to be 72-300 Gt $\mathrm{CO}_{2}$ by 2050 (is predicted for 2020-2050) [34]. This figure varies depending on three distinct factors, kinds of biomaterials using for combustion, the percentage of biomass combined with fossil fuel and the technologies that use for capturing the $\mathrm{CO}_{2}$ such as; oxy-fuel combustion capture, pre combustion capture, post combustion capture, and chemical looping process [59].

Table 3. Assessment of CO2 capture capacity and cost

\begin{tabular}{|c|c|l|}
\hline Technique & $\begin{array}{c}\text { Potential capacity } \\
\mathrm{Gt} \mathrm{CO}_{2} \text { Per year }\end{array}$ & $\begin{array}{l}\text { Cost estimates } \\
\$ \text { per ton } \mathrm{CO}_{2}\end{array}$ \\
\hline BECCS & $2.4-10[59]$ & $15-400[14]$ \\
\hline Absorption & $10[59]$ & $40-600[68]$ \\
\hline Adsorption & $10[59]$ & $40-600[68]$ \\
\hline
\end{tabular}




\section{COST ESTIMATES}

Table 3 represents the cost estimates of BECCS, absorption and adsorption processes per ton $\mathrm{CO}_{2}$ stored, these figures have collected according to the literature. Generally, cost estimates mentioned in the literature are changed from $\$ 8$ to more than $\$ 1000$ per ton of $\mathrm{CO}_{2}$ is captured by NETs [58].

The BECCS cost was estimated by researchers in different literature according to their criteria and consideration, most of the figures was calculated fairly optimistic for 2020 or even 2030, especially when the deployment of CCS generally remains slow, and a value of $\$ 150 / \mathrm{COO}_{2}$ is considered for this process, as presents in table 3 this figure is $\$ 15-400 / \mathrm{tCO}_{2}$, varying widely according to CCS process and kinds of biomaterial utilizing in this technology [14].

Keith et al [40] report the cost of captured $\mathrm{CO}_{2}$ around $\$ 70 / \mathrm{t} \mathrm{CO}_{2}$ from the air. While IEAGHG [31] cites costs of \$70-110/t- $\mathrm{CO}_{2}$ avoided for BECCS, Karlsson et al [37] suggest, more optimistically, costs of BECCS in Sweden between \$75$95 / \mathrm{t}-\mathrm{CO}_{2}$ by 2020 , and significantly lower by 2030 .

The cost of absorption and adsorption technologies were estimated to be at the range of $\$ 40-600 / \mathrm{t}-\mathrm{CO}_{2}$ according to operation parameters [68]. For example for the only existing commercial direct air capture machine which is depicted in fig $3, \mathrm{CO}_{2}$ captures at a cost of $\$ 600 / \mathrm{t} \mathrm{O}_{2}[68]$.

\section{CONCLUSIONS}

Despite the low concentration of $\mathrm{CO}_{2}$ in the atmosphere, $\mathrm{CO}_{2}$ capture with direct and indirect way from the atmosphere with utilizing negative emission technologies seem to be powerful techniques to mitigate the dire consequence of climate change. According to the findings of this work, the potential capacity of $\mathrm{CO}_{2}$ capture for absorption and adsorption technologies is more than BECCS. However, the price of capturing $\mathrm{CO}_{2}$ for these two technologies, in most cases, are more than BECCS. Besides, the constraints regarding the BECCS are much more than two other techniques.

Owing to this assessment, NETs, in turn, failed to be considered as an economically effective alternative for mitigation of global warming in the coming decades. Significant technological development and adequate international subsidization would be necessary to overcome such constraints and reduce the cost of utilizing these technologies.

Indeed, NETs should be seen as a complementary action to achieve climate targets until the end of this century. The combination of these technologies with other conventional methods may reduce the overall costs of the process. 


\section{REFERENCES}

1. Abergel, T et al. 2017. Energy technology perspectives 2017: Catalysing energy technology transformations. OECD.

2. Alexander, L, Allen, S and Bindoff, N.L 2013. Working group I contribution to the IPCC fifth assessment report climate change: the physical science basis summary for policymakers. OPCC.

3. Allen, M.R et al. 2009 .Warming caused by cumulative carbon emissions towards the trillionth tonne. Nature 458, 1163-1166.

4. Azadi, M, Northey, S.A, Ali, S.H and Edraki, M 2020. Transparency on greenhouse gas emissions from mining to enable climate change mitigation. Nature Geoscience 13(2), 100-104.

5. Baciocchi, R, Storti, G and Mazzotti, M 2006. Process design and energy requirements for the capture of carbon dioxide from air. Chemical Engineering and Processing: Process Intensification 45(12), 1047-1058.

6. Bednar, J, Obersteiner, M and Wagner, F 2019. On the financial viability of negative emissions. Nature communications 10(1), 1-4.

7. Broehm, M, Strefler, J and Bauer, N.2015. Techno-economic review of direct air capture systems for large scale mitigation of atmospheric $\mathrm{CO}_{2}$. Available at SSRN 2665702.

8. Bui, M, Fajardy, M and Mac Dowell, N 2017. Bio-Energy with CCS (BECCS) performance evaluation: Efficiency enhancement and emissions reduction. Applied energy 195, 289-302.

9. Cabral, R.P, Bui, M and Mac Dowell, N 2019. A synergistic approach for the simultaneous decarbonisation of power and industry via bioenergy with carbon capture and storage (BECCS). International Journal of Greenhouse Gas Control 87, 221-237.

10. Cai, T., Park, S.Y. and Li, Y 2013.Nutrient recovery from wastewater streams by microalgae: status and prospects. Renewable and Sustainable Energy Reviews 19, 360-369.

11. Canadell, J.G, Raupach, M.R 2008. Managing forests for climate change mitigation. Science 320.5882, 1456-1457.

12. Chiu, S. Y et al. 2011. Microalgal biomass production and on-site bioremediation of carbon dioxide, nitrogen oxide and sulfur dioxide from flue gas using Chlorella sp. cultures, Bioresource Technology 102, 9135-9142.

13. Choi, Y.Y, Patel, A.K, Hong, M.E, Chang, W.S and Sim, S.J 2019. Microalgae Bioenergy with Carbon Capture and Storage (BECCS): An emerging sustainable bioprocess for reduced $\mathrm{CO}_{2}$ emission and biofuel production. Bioresource Technology Reports 7, 10027.

14. Consoli, C, 2019. Bioenergy and carbon capture and storage. Global CCS Institute. 
15. Creutzig, $\mathrm{F}$ et al. 2015. Bioenergy and climate change mitigation: an assessment. Global Change Biology Bioenergy 7, 916-944.

16. Cumicheo, C, Mac Dowell, N and Shah, N 2019. Natural gas and BECCS: A comparative analysis of alternative configurations for negative emissions power generation. International Journal of Greenhouse Gas Control 90, 102798

17. Dawson, T.P, Jackson, S.T, House, J.I, Prentice, I.C and Mace, G.M 2011. Beyond predictions biodiversity conservation in a changing climate. Science 332, 53-58.

18. De Coninck, H and Rubin, E 2005. IPCC special report on carbon dioxide capture and storage. UK: Cambridge University Press. TNO: Cost Curves for $\mathrm{CO}_{2}$ Storage, Part 2, 14.

19. Durgadevi, A and Pushpavanam, S 2018. An experimental and theoretical investigation of pure carbon dioxide absorption in aqueous sodium hydroxide in glass millichannels. Journal of $\mathrm{CO}_{2}$ Utilization 26, 133-142.

20. EASAC, 2018. Negative emission technologies: What role in meeting Paris agreement targets?. EASAC Policy Report 35, 45.

21. Edenhofer, $\mathrm{O}$ et al. 2011. Renewable energy sources and climate change mitigation: Special report of the intergovernmental panel on climate change. Cambridge University Press.

22. Edenhofer, O. ed 2015. Climate change 2014: mitigation of climate change (Vol. 3). Cambridge University Press.

23. Edmonds, J et al. 2013. Can radiative forcing be limited to $2.6 \mathrm{Wm}-2$ without negative emissions from bioenergy and $\mathrm{CO}_{2}$ capture and storage?. Climate Change118, 29-43.

24. Farrelly, D.J, Everard, C.D, Fagan, C.C and McDonnell, K.P 2013. Carbon sequestration and the role of biological carbon mitigation: a review. Renewable and sustainable energy reviews 21,712-727.

25. Fuss, S et al. 2014. Betting on negative emission. Natural Climate Change 4, $850-853$.

26. Gasser, T, Guivarch, C, Tachiiri, K, Jones, C.D and Ciais, P 2015. Negative emissions physically needed to keep global warming below $2{ }^{\circ} \mathrm{C}$. Nature communications 6(1), 1-7.

27. Giagnoni, L et al. 2019. Long-term soil biological fertility, volatile organic compounds and chemical properties in a vineyard soil after biochar amendment. Geoderma 344, 127-136.

28. Goeppert, A, Czaun, M, Prakash, G.S and Olah, G.A 2012. Air as the renewable carbon source of the future: an overview of $\mathrm{CO}_{2}$ capture from the atmosphere. Energy \& Environmental Science 5(7), 7833-7853. 
29. Gutknecht, V, Snæbjörnsdóttir, S.Ó, Sigfússon, B, Aradóttir, E.S and Charles, L 2018. Creating a carbon dioxide removal solution by combining rapid mineralization of $\mathrm{CO}_{2}$ with direct air capture. Energy Procedia 146,129-134.

30. Herzog, H. J and Drake, E. M 1996. Carbon dioxide recovery and disposal from large energy systems. Annual review of energy and the environment 21(1), 145-166.

31. Hoefnagels, E.T.A, Junginger, H.M, Resch, G, Matzenberger, J, Panzer, C and Pelkmans, L 2011. Development of a tool to model European biomass trade: Report for IEA Bioenergy Task 40.

32. Houghton, J 1990. Scientific assessment of climate change: the policymakers' summary of the report of working group 1 to Intergovernmental Panel on Climate Change. Scientific assessment of climate change: the policymakers' summary of the report of working group 1 to Intergovernmental Panel on Climate Change.

33. House, K.Z, Baclig, A.C, Ranjan, M, van Nierop, E.A, Wilcox, J and Herzog, H.J 2011. Economic and energetic analysis of capturing $\mathrm{CO}_{2}$ from ambient air. Proceedings of the National Academy of Sciences 108(51), 20428-20433.

34. House, K.Z, House, C.H, Schrag, D.P and Aziz, M.J 2007. Electrochemical acceleration of chemical weathering as an energetically feasible approach to mitigating anthropogenic climate change. Environmental Science \& Technology 41(24), 8464-8470.

35. $\mathrm{Hu}, \mathrm{L}$ et al. 2017. Considerable contribution of the Montreal Protocol to declining greenhouse gas emissions from the United States. Geophysical Research Letters 44(15), 8075-8083.

36. Humpenöder, F etal. 2014. Investigating afforestation and bioenergy CCS as climate change mitigation strategies. Environmental Research Letters 9(6), 064029 .

37. Karlsson, H, Byström, L and Wiklund, J 2010. BECCS som klimatåtgärd. Biorecro AB, Stockholm, Sweden.

38. Kato, E, Moriyama, R and Kurosawa, A 2017. A sustainable pathway of bioenergy with carbon capture and storage deployment. Energy Procedia 114, 6115-6123.

39. Keith, D.W 2009. Why capture $\mathrm{CO}_{2}$ from the atmosphere?. Science 325, 1654-1655.

40. Keith, D.W, Ha-Duong, $\mathrm{M}$ and Stolaroff, J.K 2006. Climate strategy with $\mathrm{CO}_{2}$ capture from the air. Climatic Change 74(1), 17-45.

41. Keith, D.W, Holmes, G, Angelo, D.S and Heidel, K 2018. A process for capturing $\mathrm{CO}_{2}$ from the atmosphere. Joule 2(8), 1573-1594.

42. Keith, D.W and Rhodes, J.S 2002. Bury, burn or both: a two-for-one deal on biomass carbon and energy. Climatic Change 54(3), 375. 
43. Kelemen, P.B and Matter, J 2008. In situ carbonation of peridotite for $\mathrm{CO}_{2}$ storage. Proceedings of the National Academy of Sciences 105(45), 1729517300 .

44. Kraxner, $F$ et al. 2014. BECCS in South Korea-Analyzing the negative emissions potential of bioenergy as a mitigation tool. Renewable Energy $\mathbf{6 1}$, 102-108.

45. Kraxner, F, Nilsson, S and Obersteiner, M 2003. Negative emissions from BioEnergy use, carbon capture and sequestration (BECS) - the case of biomass production by sustainable forest management from semi-natural temperate forests. Biomass and Bioenergy 24, 285-296.

46. Krey, V, Luderer, G, Clarke, L and Kriegler, E 2014. Getting from here to there-energy technology transformation pathways in the EMF27 scenarios. Climatic change 123(3), 369-382.

47. Lackner, K.S 2009. Capture of carbon dioxide from ambient air. The European Physical Journal Special Topics 176(1), 93-106.

48. Lackner, K, Ziock, H.J and Grimes, P 1999. Carbon dioxide extraction from air: is it an option?. Los Alamos National Lab, NM (US).

49. Larkin, A, Kuriakose, J, Sharmina, M and Anderson, K 2018. What if negative emission technologies fail at scale? Implications of the Paris Agreement for big emitting nations. Climate policy 18.6, 690-714.

50. Lenes, J.M et al. 2001. Iron fertilization and the Trichodesmium response on the West Florida shelf. Limnology and Oceanography 46, 1261-1277.

51. Lenton, TM and Vaughan, NE 2009. The radiative forcing potential of different climate geoengineering options. Atmospheric Chemistry and Physics 9(15), 5539-5561.

52. Leung, D.Y, Caramanna, G and Maroto-Valer, M.M 2014. An overview of current status of carbon dioxide capture and storage technologies. Renewable and Sustainable Energy Reviews 39, 426-443.

53. Li, M, Zhou, M, Tan, $\mathrm{C}$ and Tian, X 2019. Enhancement of $\mathrm{CO}_{2}$ biofixation and bioenergy generation using a novel airlift type photosynthetic microbial fuel cell. Bioresource technology 272, 501-509.

54. Low, S and Schäfer, S 2020. Is bio-energy carbon capture and storage (BECCS) feasible? The contested authority of integrated assessment modeling. Energy Research \& Social Science 60, 101326.

55. Lu, J.G, CHENG, M.D, Yan, J.I and Zhang, H 2009. Membrane-based $\mathrm{CO}_{2}$ absorption into blended amine solutions. Journal of Fuel Chemistry and Technology 37(6), 740-746.

56. Lueker, T.J, Dickson, A.G and Keeling, C.D 2000. Ocean $\mathrm{CO}_{2}$ calculated from dissolved inorganic carbon, alkalinity, and equations for $\mathrm{K}_{1}$ and $\mathrm{K}_{2}$; validation based on laboratory measurements of $\mathrm{CO}_{2}$ in gas and seawater at equilibrium. dMarine Chemistry 70, 105-119. 
57. Maciejewska, A.K, Peteves, S.D, Sanders, J.P.M and Veringa, H 2006. Cofiring of biomass with coal: constraints and role of biomass pretreatment. Office for Official Publications of the European Communities.

58. McGlashan, N, Shah, N and Workman, M 2010. The potential for the deployment of negative emissions technologies in the UK. Work stream 2.

59. McLaren, D 2012. A comparative global assessment of potential negative emissions technologies. Process Safety and Environmental Protection 90(6), 489-500.

60. Mendiara, $\mathrm{T}$ et al. 2018. Negative $\mathrm{CO}_{2}$ emissions through the use of biofuels in chemical looping technology: a review. Applied energy 232, 657-684.

61. Meinshausen, $M$ et al. 2009. Greenhouse-gas emission targets for limiting global warming to $2{ }^{\circ} \mathrm{C}$. Nature 458, 1158-1162.

62. Möllersten, K and Yan, J 2001. Economic evaluation of biomass-based energy systems with $\mathrm{CO}$ sub (2) capture and sequestration in kraft pulp mills- The influence of the price of CO sub (2) emission quota. World Resource Review 13(4), 509-525.

63. Moreira, J.R, Romeiro, V, Fuss, S, Kraxner, F and Pacca, S.A 2016. BECCS potential in Brazil: Achieving negative emissions in ethanol and electricity production based on sugar cane bagasse and other residues. Applied Energy 179, 55-63.

64. Murdock, C.R, Didas, S.A and Jones, C.W 2016. Direct capture of $\mathrm{CO}_{2}$ from ambient air. Chemical reviews 116(19), 11840-11876.

65. Nemet, G.F et al. 2018. Negative emissions-Part 3: Innovation and upscaling. Environmental Research Letters 13.6, 063003.

66. Panoutsou, C, Eleftheriadis, J and Nikolaou, A 2009. Biomass supply in EU27 from 2010 to 2030. Energy Policy 37(12), 5675-5686.

67. Peters, G.P et al. 2013. The challenge to keep global warming below $2{ }^{\circ} \mathrm{C}$. Natural Climate Change 3, 4-6.

68. Pires, J. C. M 2019. Negative emissions technologies: A complementary solution for climate change mitigation. The Science of the total environment 672, 502-514.

69. Pour, N, Webley, P.A and Cook, P.J 2017. A sustainability framework for bioenergy with carbon capture and storage (BECCS) technologies. Energy Procedia 114, 6044-6056.

70. Pour, N, Webley, P.A and Cook, P.J 2018. Opportunities for application of BECCS in the Australian power sector. Applied Energy 224, 615-635.

71. Ranjan, M and Herzog, H.J 2011. Feasibility of air capture. Energy Procedia 4, 2869-2876.

72. Read, P and Lermit, J 2005. Bio-energy with carbon storage (BECS): A sequential decision approach to the threat of abrupt climate change. Energy 30(14), 2654-2671. 
73. Realff, M.J and Eisenberger, P 2012. Flawed analysis of the possibility of air capture. Proceedings of the National Academy of Sciences of the USA 109(25), E1589.

74. Riahi, K et al. 2015. Locked into Copenhagen pledges - implications of short term emission targets for the cost and feasibility of long-term climate goals. Technological Forecasting and Social Change 90, 8-23.

75. Rickaby, R.E, Elderfield, H, Roberts, N, Hillenbrand, C.D and Mackensen, A 2010. Evidence for elevated alkalinity in the glacial Southern Ocean. Paleoceanography 25(1).

76. Rockström, J et al. 2009. A safe operating space for humanity. Nature 461, 472-475.

77. Rogelj, $\mathrm{J}$ et al. 2016. Differences between carbon budget estimates unravelled. Nature Climate Change 6.3, 245-252.

78. Rogelj, J, McCollum, D.L, Reisinger, A, Meinshausen, M and Riahi, K 2013. Probabilistic cost estimates for climate change mitigation. Nature 493(7430), 79-83.

79. Rogelj, J et al. 2016. Paris Agreement climate proposals need a boost to keep warming well below $2{ }^{\circ} \mathrm{C}$. Nature 534, 631-639.

80. Russell, A.E, Laird, D.A, Parkin, T.B and Mallarino, A.P 2005. Impact of nitrogen fertilization and cropping system on carbon sequestration in Midwestern Mollisols. Soil Science Society of America Journal 69(2), 413422.

81. Rydén, $\mathrm{M}$ et al. 2017. Negative $\mathrm{CO}_{2}$ emissions with chemical-looping combustion of biomass - a Nordic energy research flagship project. Energy Procedia 114, 6074-6082.

82. Sanchez, D.L, Nelson, J.H, Johnston, J, Mileva, A and Kammen, D.M 2015. Biomass enables the transition to a carbon-negative power system across western North America. Nature Climate Change 5(3), 230-234.

83. Schakel, W, Meerman, H, Talaei, A, Ramírez, A and Faaij, A 2014. Comparative life cycle assessment of biomass co-firing plants with carbon capture and storage. Applied Energy 131, 441-467.

84. Schmidt, J, Leduc, S, Dotzauer, E and Schmid, E 2011. Cost-effective policy instruments for greenhouse gas emission reduction and fossil fuel substitution through bioenergy production in Austria. Energy Policy 39(6), 3261-3280.

85. Sheng, J, Han, X and Zhou, H 2017. Spatially varying patterns of afforestation/reforestation and socio-economic factors in China: a geographically weighted regression approach." Journal of Cleaner Production 153, 362-371.

86. Simon, A.J, Kaahaaina, N.B, Friedmann, S.J and Aines, R.D et al. 2011. Systems analysis and cost estimates for large scale capture of carbon dioxide from air. Energy Procedia 4, 2893-2900. 
87. Socolow, R et al. 2011. Direct air capture of $\mathrm{CO}_{2}$ with chemicals: a technology assessment for the APS Panel on Public Affairs. American Physical Society.

88. Solomon, S 2007. The physical science basis: Contribution of Working Group I to the fourth assessment report of the Intergovernmental Panel on Climate Change. Intergovernmental Panel on Climate Change (IPCC), Climate change, 996.

89. Steffen, W, Crutzen, P.J and McNeill, J.R 2007.The Anthropocene: are humans now overwhelming the great forces of nature. The Globalization and Environment Reader 36, 614-621.

90. Tokarska, K.B, Zickfeld, K 2015. The effectiveness of net negative carbon dioxide emissions in reversing anthropogenic climate change. Environmental Research Letters 10(9), 094013.

91. Tokimatsu, K, Konishi, S, Ishihara, K, Tezuka, T, Yasuoka, R and Nishio, M 2016. Role of innovative technologies under the global zero emissions scenarios. Applied Energy 162, 1483-1493.

92. Torvanger, A 2019. Governance of bioenergy with carbon capture and storage (BECCS): accounting, rewarding, and the Paris agreement. Climate Policy 19(3), 329-341.

93. Van Vuuren, D.P, Deetman, S, van Vliet, J, van den Berg, M, van Ruijven, B.J and Koelbl, B 2013. The role of negative $\mathrm{CO}_{2}$ emissions for reaching $2^{\circ} \mathrm{C}$ -insights from integrated assessment modelling. Climatic Change 118(1), 15-27.

94. Vaughan, N.E and Gough, C 2016. Expert assessment concludes negative emissions scenarios may not deliver. Environmental research letters 11(9), 095003.

95. Whiteley, N.M 2011. Physiological and ecological responses of crustaceans to ocean acidification. Marine Ecology Progress Series 430, 257-271.

96. Wilcox, J, Psarras, P.C and Liguori, S 2017. Assessment of reasonable opportunities for direct air capture. Environmental Research Letters 12(6), 065001.

97. Williamson, P et al. 2012. Ocean fertilization for geoengineering: A review of effectiveness, environmental impacts and emerging governance. Process Safety and Environmental Protection 90(6), 475-488.

98. Williams, R.H 1998. Fuel decarbonization for fuel cell applications and sequestration of the separated $\mathrm{CO}_{2}$. Ecorestructuring: Implications for Sustainable Development.

99. Woolf, D, Amonette, J.E, Street-Perrott, F.A, Lehmann, J and Joseph, S 2010. Sustainable biochar to mitigate global climate change. Nature communications 1(1), 1-9. 
100. Wurzbacher, J.A, Gebald, C and Steinfeld, A 2011. Separation of CO2 from air by temperature-vacuum swing adsorption using diamine-functionalized silica gel. Energy \& Environmental Science 4(9), 3584-3592.

101. $\mathrm{Xu}, \mathrm{E}, \mathrm{Zhang}, \mathrm{H}$ and $\mathrm{Xu}, \mathrm{Y} 2020$. Exploring land reclamation history: Soil organic carbon sequestration due to dramatic oasis agriculture expansion in arid region of Northwest China. Ecological Indicators 108, 105746.

102. Yu, C.H, Huang, C.H and Tan, C.S 2012. A review of $\mathrm{CO} 2$ capture by absorption and adsorption. Aerosol and Air Quality Research 12(5), 745-769.

103. Zaman, M and Lee, J.H 2013. Carbon capture from stationary power generation sources: A review of the current status of the technologies. Korean Journal of Chemical Engineering 30(8), 1497-1526.

104. Zeman, F.S and Lackner, K.S 2004. Capturing carbon dioxide directly from the atmosphere. World Resource Review 16(2), 157-172.

105. Zeman, F 2007. Energy and material balance of $\mathrm{CO}_{2}$ capture from ambient air. Environmental science \& technology 41(21), 7558-7563.

Editor received the manuscript: 15.09.2020 